\title{
Polaromonas glacialis sp. nov. and Polaromonas cryoconiti sp. nov., isolated from alpine glacier cryoconite
}

\author{
Rosa Margesin, ${ }^{1}$ Cathrin Spröer, ${ }^{2}$ De-Chao Zhang ${ }^{1}$ \\ and Hans-Jürgen Busse ${ }^{3}$
}

Correspondence
Rosa Margesin
Rosa.Margesin@uibk.ac.at

\author{
${ }^{1}$ Institute of Microbiology, University of Innsbruck, Technikerstrasse 25, A-6020 Innsbruck, Austria \\ ${ }^{2}$ Leibniz-Institut DSMZ Deutsche Sammlung für Mikroorganismen und Zellkulturen $\mathrm{GmbH}$, \\ Inhoffenstrasse 7B, D-38124 Braunschweig, Germany \\ ${ }^{3}$ Institute of Bacteriology, Mycology and Hygiene, University of Veterinary Medicine Vienna, \\ Veterinärplatz 1, A-1210 Vienna, Austria
}

The taxonomic positions of two Gram-staining-negative, psychrophilic bacteria, which were isolated from alpine glacier cryoconite and designated strains $\mathrm{Cr} 4-12^{\top}$ and $\mathrm{Cr} 4-35^{\top}$, were investigated using a polyphasic approach. Both novel strains contained ubiquinone $\mathrm{Q}-8$ as the sole quinone, summed feature $3\left(\mathrm{C}_{16: 1} \omega 7 \mathrm{c}\right.$ and/or $\left.\mathrm{C}_{16: 1} \omega 6 \mathrm{c}\right)$ and $\mathrm{C}_{16: 0}$ as the dominant cellular fatty acids, putrescine and 2-hydroxyputrescine as the major polyamines, and diphosphatidylglycerol, phosphatidylglycerol and phosphatidylethanolamine as the major polar lipids. The genomic DNA G $+\mathrm{C}$ contents of strains $\mathrm{Cr} 4-12^{\top}$ and $\mathrm{Cr} 4-35^{\top}$ were $61.3 \mathrm{~mol} \%$ and $60.7 \mathrm{~mol} \%$, respectively. Phylogenetic analysis based on 16S rRNA gene sequences indicated that the two strains belonged to the genus Polaromonas. Although the $16 \mathrm{~S}$ rRNA gene sequences of strains $\mathrm{Cr} 4-12^{\top}$ and $\mathrm{Cr} 4-35^{\top}$ were very similar ( $98.7 \%$ sequence similarity), hybridizations indicated a DNA-DNA relatedness value of only $26.9 \%$ between the two novel strains. In pairwise comparisons with the type strains of recognized Polaromonas species, strains Cr4-12 ${ }^{\top}$ and $\mathrm{Cr} 4-35^{\top}$ showed 16S rRNA gene sequence similarities of 96.4-98.5 \% and 96.5$98.4 \%$, respectively. Based on the phenotypic and phylogenetic evidence and DNA-DNA relatedness data, strains $\mathrm{Cr} 4-12^{\top}$ and $\mathrm{Cr} 4-35^{\top}$ represent two novel species within the genus Polaromonas, for which the names Polaromonas glacialis sp. nov. and Polaromonas cryoconitisp. nov., respectively, are proposed. The type strain of Polaromonas glacialis sp. nov. is Cr4-12 ${ }^{\top}$

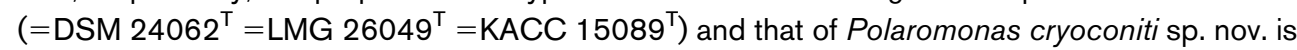

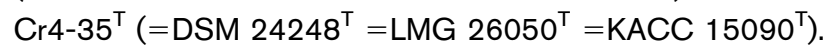

The genus Polaromonas was proposed by Irgens et al. (1996) for a species of psychrophilic, marine, gas-vacuolate bacterium isolated from Antarctica (Polaromonas vacuolata). At the time of writing, this genus comprised five species: Polaromonas naphthalenivorans (Jeon et al., 2004), Polaromonas aquatica (Kämpfer et al., 2006), Polaromonas hydrogenivorans (Sizova \& Panikov, 2007), Polaromonas jejuensis (Weon et al., 2008) and the type species, P. vacuolata.

Members of the genus Polaromonas have been isolated from various environmental sources, such as tap water

The GenBank/EMBL/DDBJ accession numbers for the $16 \mathrm{~S}$ rRNA gene sequences of strains $\mathrm{Cr} 4-12^{\top}$ and $\mathrm{Cr} 4-35^{\top}$ are $\mathrm{HM} 583568$ and HM583567, respectively.

A supplementary table and a supplementary figure are available with the online version of this paper.
(Kämpfer et al., 2006), marine water (Irgens et al., 1996), sediment (Jeon et al., 2004) and soil (Sizova \& Panikov, 2007; Weon et al., 2008). Polaromonas species have been found in contaminated environments, where they may play a role as degraders of hydrocarbons and xenobiotics (Jeon et al., 2004; Mattes et al., 2008; Yagi et al., 2009), and in pristine environments. The geographical regions of isolation range from Antarctica (Irgens et al., 1996) to Alaska (Sizova \& Panikov, 2007). As members of the genus Polaromonas are among the dominant bacteria of glacial ice and glacial sediments worldwide, including polar and highelevation environments (Darcy et al., 2011), it is not surprising that most members are able to grow well at relatively low temperatures. Polaromonas phylotypes are characterized by a high local diversity (which is nearly equivalent to their global diversity) and they may be globally distributed, as dormant cells, in high-elevation air 
currents (Darcy et al., 2011). Genomic studies have revealed extreme metabolic diversity within the genus Polaromonas, possibly as the result of extensive horizontal gene transfer (Yagi et al., 2009).

Two Gram-staining-negative, psychrophilic bacteria, designated strains $\mathrm{Cr} 4-12^{\mathrm{T}}$ and $\mathrm{Cr} 4-35^{\mathrm{T}}$, were among the strains isolated by Zhang et al. (2012) from cryoconite that had been collected from the Pasterze/Großglockner glacier in the Hohe Tauern, Austria, at an altitude of $2200 \mathrm{~m}$ above sea level. The taxonomic positions of these two novel strains were investigated by following a polyphasic approach. Pure cultures of both strains were routinely cultured, at $20{ }^{\circ} \mathrm{C}$, on R2A agar containing $\left(\mathrm{l}^{-1}\right) 0.5$ g yeast extract, $0.5 \mathrm{~g}$ peptone, $0.5 \mathrm{~g}$ Casamino acids, $0.5 \mathrm{~g}$ glucose, $0.5 \mathrm{~g}$ starch, $0.3 \mathrm{~g}$ sodium pyruvate, $0.3 \mathrm{~g} \mathrm{~K} \mathrm{HPO}_{4}, 0.05 \mathrm{~g}$ $\mathrm{MgSO}_{4}$ and $15.0 \mathrm{~g}$ agar (pH 7; Reasoner \& Geldreich, 1985). Both were also stored as suspensions in skim milk $(10 \%, \mathrm{w} / \mathrm{v})$ at $-80{ }^{\circ} \mathrm{C}$. For reference, $P$. naphthalenivorans DSM $15660^{\mathrm{T}}, P$. jejuensis KACC $12508^{\mathrm{T}}, P$. hydrogenivorans KACC $12646^{\mathrm{T}}$ and $P$. aquatica CCUG $39402^{\mathrm{T}}$ were obtained and routinely grown on R2A agar at $20{ }^{\circ} \mathrm{C}$.

DNA was extracted from each novel strain and purified, as described by Sambrook et al. (1989), so that the 16S rRNA genes could be amplified by PCR with the universal primers 27F (5'-AGAGTTTGATCCTGGCTCAG-3') and 1541R (5'AAGGAGGTGATCCAGCCGCA-3'). Each amplification product was cloned into the pGEM-T Easy vector (Promega) before the recombinant plasmid was propagated in Escherichia coli according to the vector manufacturer's instructions (Zhang et al., 2011). Sequencing was carried out by Eurofins MWG Operon (Ebersberg, Germany) using version 3.1 of the ABI Big Dye Terminator kit (Applied Biosystems) and the ABI PRISM 3730xl automated DNA sequencer (Applied Biosystems). Version 1.8 of CLUSTAL_X (Thompson et al., 1997) was used to align the newly determined sequences with 16S rRNA gene sequences retrieved from GenBank/EMBL before phylogenetic analysis was carried out, and neighbour-joining (Saitou \& Nei, 1987) and maximum-likelihood (Felsenstein, 1981) trees were constructed, using version 5.0 of the MEGA software package (Tamura et al., 2011). In pairwise comparisons with the type strains of recognized Polaromonas species, which were made using the Kimura two-parameter model, strains $\mathrm{Cr} 4-12^{\mathrm{T}}$ and $\mathrm{Cr} 4-35^{\mathrm{T}}$ showed $16 \mathrm{~S}$ rRNA gene sequence similarities of $96.4-98.5 \%$ and $96.5-98.4 \%$, respectively. In these comparisons, strains $\mathrm{Cr} 4-12^{\mathrm{T}}$ and $\mathrm{Cr} 4-35^{\mathrm{T}}$ appeared to be least closely related to the type strain of the type species of the genus Polaromonas, $P$. vacuolata $34-\mathrm{P}^{\mathrm{T}}$, with sequence similarities of $96.4 \%$ and $96.5 \%$, respectively. The $16 \mathrm{~S}$ rRNA genes of strains $\mathrm{Cr} 4-$ $12^{\mathrm{T}}$ and $\mathrm{Cr} 4-35^{\mathrm{T}}$ were very similar $(98.7 \%$ sequence similarity). In the neighbour-joining phylogenetic tree, the two novel strains formed a distinct cluster in a phyletic line that they shared with $P$. naphthalenivorans and $P$. hydrogenivorans (Fig. 1). The maximum-likelihood tree displayed a similar topology (Fig. 1).
Cell morphology was examined under a phase-contrast light microscope (Diaplan; Leitz) and in a transmission electron microscope (Libra 120 EFTEM; Zeiss), using cells that had been grown on R2A agar at $20{ }^{\circ} \mathrm{C}$. Motility was also investigated by light microscopy. Gram staining was performed by using a Gram staining kit (bioMérieux) according to the manufacturer's instructions. Catalase activity was evaluated as bubble production in $3 \%(\mathrm{v} / \mathrm{v})$ $\mathrm{H}_{2} \mathrm{O}_{2}$ while cytochrome $c$ oxidase activity was determined using $1 \%(\mathrm{w} / \mathrm{v}) \quad N, N, N^{\prime}, N^{\prime}$-tetramethyl-p-phenylenediamine. Physiological and biochemical characteristics and other enzyme activities were determined by using the API $20 \mathrm{E}$, API $20 \mathrm{NE}$ and API ZYM systems (bioMérieux) at $20{ }^{\circ} \mathrm{C}$. The assimilation of glucose, maltose, sucrose, Larabinose, mannose, D-sorbitol, myo-inositol, salicin, $\mathrm{N}$ acetyl-D-glucosamine, Tween 40 and Tween 80 as sole carbon sources was also tested at $20{ }^{\circ} \mathrm{C}$ in mineral medium, as described by Zhang et al. (2010). To test for a vitamin requirement for growth, strains were cultured in the same mineral medium, with Tween 40 (which was utilized as a sole carbon source for growth by all the strains investigated) and with or without the vitamin solution described by Schlegel (1992). The ability to utilize naphthalene as the sole carbon and energy source was tested on mineral medium agar (Margesin \& Schinner, 1997) without yeast extract. A stock solution of naphthalene $\left(10 \mathrm{mg} \mathrm{ml}^{-1}\right)$ was dissolved in diethyl ether and sprayed on plates of the agar. The diethyl ether was then allowed to evaporate before the plates were inoculated with suspensions of bacterial cells in $0.9 \%(\mathrm{w} / \mathrm{v}) \mathrm{NaCl}$. Naphthalene utilization was also tested by using the vapour-plate method (Foght \& Aislabie, 2005). For this, naphthalene crystals $(50 \mathrm{mg}$ ) were placed on a small piece of filter paper that was then placed in an inverted, inoculated agar plate. Each plate was then sealed and incubated in a sealed plastic bag, with growth evaluated regularly over an incubation period of 21 days. Amylase, lipase and protease activities were evaluated on R2A agar supplemented with the appropriate substrate (Margesin et al., 2003). Growth at various temperatures (ranging from $1{ }^{\circ} \mathrm{C}$ to $42{ }^{\circ} \mathrm{C}$ ) was assessed both on R2A agar and in shake cultures of R2A broth (shaken at 150 r.p.m.). Growth in medium buffered to give initial $\mathrm{pH}$ values varying from 5 to 10 and on R2A agar containing 0 $10 \%(w / v) ~ N a C l$ was also evaluated. Growth on standard R2A, nutrient agar (NA) and trypticase soy agar (TSA) containing $\left(1^{-1}\right) 15 \mathrm{~g}$ casein peptone, $5 \mathrm{~g}$ soy peptone, $5 \mathrm{~g}$ $\mathrm{NaCl}$ and $15 \mathrm{~g}$ agar, at $\mathrm{pH} 7$, was compared.

All tests were carried out simultaneously with strains Cr4$12^{\mathrm{T}}$ and $\mathrm{Cr} 4-35^{\mathrm{T}}$ and the four reference strains, with two or three replications per test. The morphological, physiological and biochemical characteristics of strains $\mathrm{Cr} 4-12^{\mathrm{T}}$ and $\mathrm{Cr} 4-35^{\mathrm{T}}$ are summarized in the species descriptions. The features that can be used to differentiate strains Cr4$12^{\mathrm{T}}$ and $\mathrm{Cr} 4-35^{\mathrm{T}}$ from each other and from the reference strains are given in Table 1.

For fatty acid analysis, strains $\mathrm{Cr} 4-12^{\mathrm{T}}$ and $\mathrm{Cr} 4-35^{\mathrm{T}}$ and the four reference strains were grown on plates of R2A agar at 


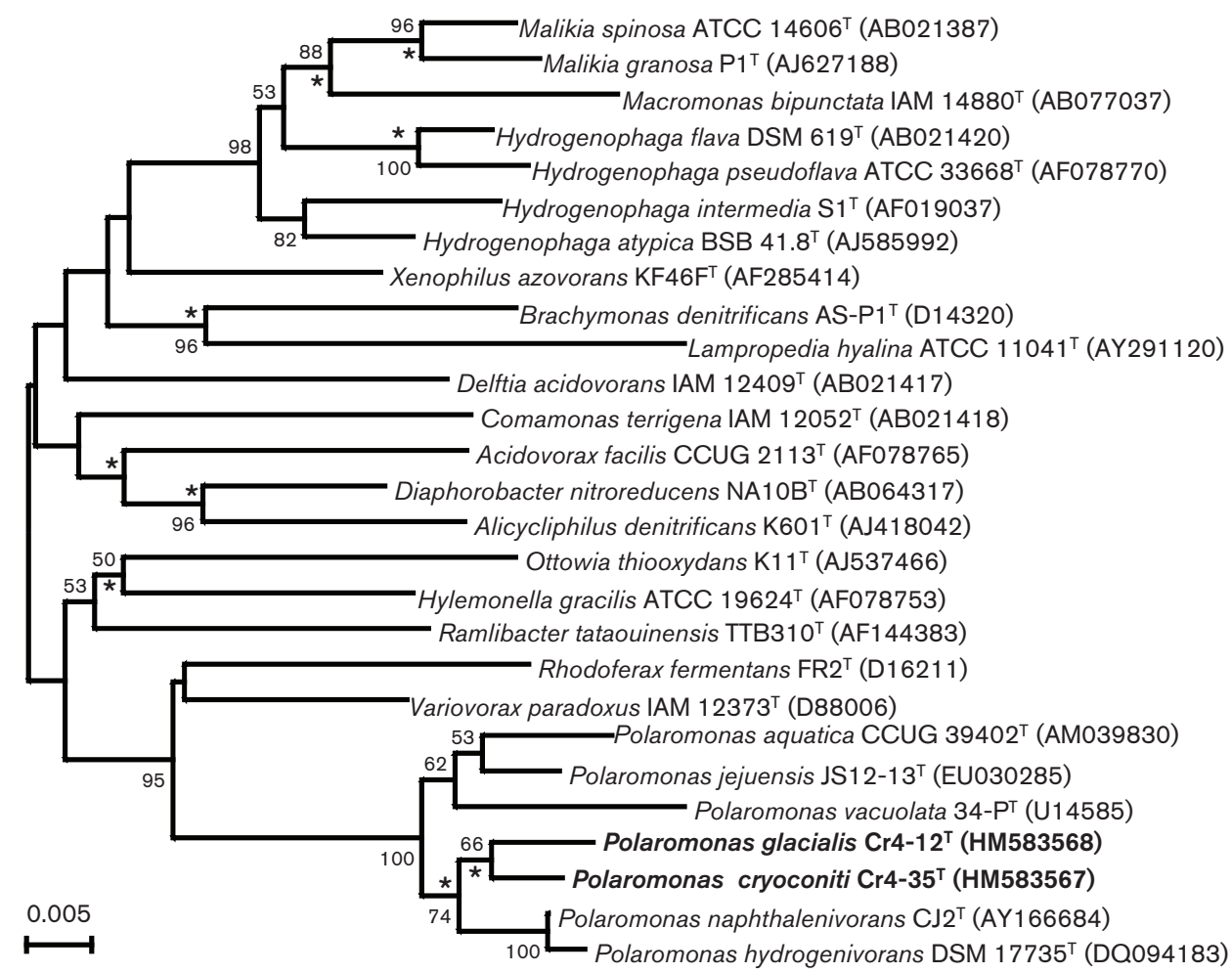

Fig. 1. Neighbour-joining tree based on $16 \mathrm{~S}$ rRNA gene sequences showing the relationships between strains $\mathrm{Cr} 4-12^{\top}$ and $\mathrm{Cr} 4-35^{\top}$, recognized members of the genus Polaromonas, and representatives of some other related taxa. Asterisks indicate that the corresponding nodes were also obtained in the maximum-likelihood tree. Bootstrap values $\geqslant 50 \%$ (based on 1000 replications) are at branch points. Bar, 0.005 substitutions per nucleotide.

$20{ }^{\circ} \mathrm{C}$ for 3 days. Under these conditions, all six strains showed similar growth behaviour and, at the end of the incubation period, sufficient cells of comparable physiological age could be harvested from the third streak quadrant on each plate. Fatty acid methyl esters were extracted, prepared and identified according to the standard protocol of version 6.1 of the Sherlock Microbial Identification System (MIDI; Sasser, 1990), using a 6890N GC (Agilent) and version 4.10 of the TSBA database. All of the analyses of cellular fatty acids were carried out by the Identification Service of the Deutsche Sammlung für Mikroorganismen und Zellkulturen (DSMZ), Braunschweig, Germany. The fatty acid profiles of strains $\mathrm{Cr} 4-12^{\mathrm{T}}$ and $\mathrm{Cr} 4-35^{\mathrm{T}}$ resembled those of members of the genus Polaromonas (Sizova \& Panikov, 2007; Weon et al., 2008; Table S1, available in IJSEM Online). The predominant cellular fatty acids of strain $\mathrm{Cr} 4-12^{\mathrm{T}}$ were summed feature $3\left(\mathrm{C}_{16: 1} \omega 7 c\right.$ and/or $\left.\mathrm{C}_{16: 1} \omega 6 c, 59.7 \%\right), \mathrm{C}_{16: 0}(15.4 \%)$ and $\mathrm{C}_{18: 1} \omega 7 c(11.9 \%)$. Those of strain $\mathrm{Cr} 4-35^{\mathrm{T}}$ were summed feature $3\left(\mathrm{C}_{16: 1} \omega 7 c\right.$ and/or $\left.\mathrm{C}_{16: 1} \omega 6 c, 60.5 \%\right)$ and $\mathrm{C}_{16: 0}(28.0 \%)$.

The respiratory quinones of the novel strains were extracted and purified according to the method of Collins (1985). They were then analysed by HPLC (Wu et al., 1989), with Q8 from $P$. naphthalenivorans DSM $15660^{\mathrm{T}}$ and P. jejuensis
KACC $12508^{\mathrm{T}}$ used for reference. The only ubiquinone found in each of the novel strains was Q-8.

For polyamine analysis, strains $\mathrm{Cr} 4-12^{\mathrm{T}}$ and $\mathrm{Cr} 4-35^{\mathrm{T}}$ were grown at $20{ }^{\circ} \mathrm{C}$ in PYE medium containing $\left(1^{-1}\right) 3.0$ g yeast extract and $3.0 \mathrm{~g}$ peptone ( $\mathrm{pH} 7)$. Polyamines were extracted as described by Busse \& Auling (1988) and analysed as described by Busse et al. (1997), using the HPLC equipment described by Stolz et al. (2007). The polyamine pattern of strain $\mathrm{Cr} 4-12^{\mathrm{T}}$ consisted of [ $\mu \mathrm{mol}$ (g dry mass $)^{-1}$ ] putrescine (77.2), 2-hydroxyputrescine (32.9), spermidine (3.0) and minor amounts of cadaverine (0.5) and spermine (0.3). The polyamine pattern of strain Cr4- $35^{\mathrm{T}}$ was similar, consisting of $\left[\mu \mathrm{mol}(\mathrm{g} \text { dry mass })^{-1}\right]$ putrescine (69.6), 2-hydroxyputrescine (26.7), spermidine (1.4) and minor amounts of cadaverine (0.6). Although both of these polyamine patterns resembled that described for $P$. aquatica, strains $\mathrm{Cr} 4-12^{\mathrm{T}}$ and $\mathrm{Cr} 4-35^{\mathrm{T}}$ contained higher amounts of putrescine and lower amounts of 2hydroxyputrescine than detected in $P$. aquatica CCUG $39402^{\mathrm{T}}$ (Kämpfer et al., 2006).

Polar lipid profiles were analysed by the TLC method of Tindall (1990a, b), with molybdatophosphoric acid, molybdenum blue, ninhydrin and $\alpha$-naphthol used to detect total lipids, phospholipids, aminolipids and glycolipids, 
Table 1. Phenotypic characteristics that differentiate strains $\mathrm{Cr} 4-12^{\top}$ and $\mathrm{Cr} 4-35^{\top}$ from closely related members of the genus Polaromonas

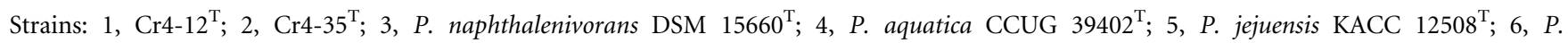
hydrogenivorans KACC $12646^{\mathrm{T}}$. All data from this study. All six strains were positive for growth on R2A, NA and TSA, growth in the absence of vitamins, catalase, cytochrome $c$ oxidase and leucine arylamidase activities and the assimilation of Tweens 40 and 80 . All were negative for motility, growth at $37{ }^{\circ} \mathrm{C}$ on R2A agar, trypsin, $\alpha$-chymotrypsin, protease (skimmed milk), $\beta$-galactosidase, $\alpha$-glucosidase, $\alpha$-mannosidase, $\alpha$-fucosidase, $N$ acetyl- $\beta$-glucosaminidase, tryptophan deaminase, lysine dihydrolase and ornithine dihydrolase activities, indole production from tryptophan, aesculin and gelatin hydrolysis, production of citrate and $\mathrm{H}_{2} \mathrm{~S}$, glucose fermentation and the assimilation of L-arabinose, D-arabinose, D-mannose, maltose, D-mannitol, $N$-acetyl-D-glucosamine, capric acid, D-sorbitol, myo-inositol and salicin. +, Positive; -, negative; w, weak.

\begin{tabular}{|c|c|c|c|c|c|c|}
\hline Isolation source & Glacier cryoconite & Glacier cryoconite & Contaminated sediment & Tap water & Soil & Forest soil \\
\hline \multicolumn{7}{|l|}{ Growth on R2A agar: } \\
\hline Growth at $1{ }^{\circ} \mathrm{C}$ & + & + & + & - & - & + \\
\hline Growth at $30{ }^{\circ} \mathrm{C}$ & - & - & - & + & + & - \\
\hline Nitrate reduction & + & + & + & - & - & + \\
\hline \multicolumn{7}{|l|}{ Enzyme activity: } \\
\hline Alkaline phosphatase & $\mathrm{w}$ & + & - & + & + & + \\
\hline Lipase (C14) & $\mathrm{W}$ & + & - & $\mathrm{w}$ & + & $\mathrm{w}$ \\
\hline$\alpha$-Galactosidase & - & - & $\mathrm{w}$ & - & - & - \\
\hline Valine arylamidase & $\mathrm{W}$ & $\mathrm{W}$ & - & $\mathrm{w}$ & + & + \\
\hline Sucrose & - & - & + & - & - & + \\
\hline Potassium gluconate & - & $\mathrm{w}$ & - & - & + & - \\
\hline Adipic acid & - & $\mathrm{W}$ & - & + & - & - \\
\hline Malic acid & - & $\mathrm{W}$ & - & + & - & - \\
\hline Trisodium citrate & - & - & - & - & + & - \\
\hline Phenylacetic acid & - & - & - & - & + & - \\
\hline Utilization of naphthalene ${ }^{*}$ & - & - & + & - & - & - \\
\hline
\end{tabular}

${ }^{*}$ As sole carbon and energy source.

respectively. The polar lipid profile of strain $\mathrm{Cr} 4-12^{\mathrm{T}}$ comprised phosphatidylglycerol, diphosphatidylglycerol, phosphatidylethanolamine, an unidentified aminolipid, three unidentified phospholipids and five unidentified polar lipids. The corresponding profile of strain $\mathrm{Cr} 4-35^{\mathrm{T}} \mathrm{com}-$ prised phosphatidylglycerol, diphosphatidylglycerol, phosphatidylethanolamine, three unidentified aminolipids and one unidentified polar lipid. Thus, the polar lipid profile of strain $\mathrm{Cr} 4-12^{\mathrm{T}}$ contained three unidentified phospholipids not seen in strain $\mathrm{Cr} 4-35^{\mathrm{T}}$, as well as at least four more unidentified polar lipids (Fig. S1).

For DNA-DNA hybridization experiments and the determination of genomic DNA G + C content, DNA was isolated from each novel strain using a French pressure cell (Thermo Spectronic) and was then purified by chromatography on hydroxyapatite, as described by Cashion et al. (1977).

The genomic DNA G $+\mathrm{C}$ contents of strains $\mathrm{Cr} 4-12^{\mathrm{T}}$ and $\mathrm{Cr} 4-35^{\mathrm{T}}$, which were determined by the Identification
Service of the DSMZ using standard HPLC (Mesbah et al., 1989), were $61.3 \mathrm{~mol} \%$ and $60.7 \mathrm{~mol} \%$, respectively.

DNA-DNA hybridization was carried out in $2 \times$ SSC buffer with $10 \%(\mathrm{v} / \mathrm{v})$ formamide at $68{ }^{\circ} \mathrm{C}$, as described by De Ley et al. (1970) with the modifications described by Huß et al. (1983). A Cary 100 Bio UV/visible spectrophotometer (Varian) equipped with a Peltier-thermostatted $6 \times 6$ multicell changer and a temperature controller with in situ temperature probe was used. The mean DNA-DNA relatedness values recorded in duplicate reassociation experiments of strain Cr4-12 $2^{\mathrm{T}}$ with $P$. aquatica CCUG $39402^{\mathrm{T}}$, P. naphthalenivorans DSM $15660^{\mathrm{T}}, P$. hydrogenivorans KACC $12946^{\mathrm{T}}$, P. jejuensis KACC $12508^{\mathrm{T}}$ and strain $\mathrm{Cr} 4-35^{\mathrm{T}}$ were $23.7,32.7$, $5.8,24.1$ and $27.0 \%$, respectively. When the recommendation of a threshold DNA-DNA relatedness value of $70 \%$ for the definition of a bacterial species (Wayne et al., 1987) is considered, these results (together with those of the phylogenetic analysis based on $16 \mathrm{~S}$ rRNA gene sequences) indicate that strain $\mathrm{Cr} 4-12^{\mathrm{T}}$ does not belong either to any established 
member of the genus Polaromonas or to the same species as strain $\mathrm{Cr} 4-35^{\mathrm{T}}$.

When, in similar experiments, the DNA from strain Cr4- $35^{\mathrm{T}}$ was hybridized with DNA samples from $P$. aquatica CCUG $39402^{\mathrm{T}}$, P. naphthalenivorans DSM $15660^{\mathrm{T}}, P$. hydrogenivorans KACC $12946^{\mathrm{T}}$ and $P$. jejuensis KACC $12508^{\mathrm{T}}$, mean DNADNA relatedness values of $11.9,25.2,26.3$ and $11.8 \%$ were recorded, respectively. These results (together with those of the phylogenetic analysis based on 16S rRNA gene sequences) indicate that strain $\mathrm{Cr} 4-35^{\mathrm{T}}$ does also not belong to any established member of the genus Polaromonas.

The data presented in this article indicate that strains Cr4$12^{\mathrm{T}}$ and $\mathrm{Cr} 4-35^{\mathrm{T}}$ are two psychrophilic members of the genus Polaromonas that, like their phylogenetic neighbours P. naphthalenivorans DSM $15660^{\mathrm{T}}$ and $P$. hydrogenivorans KACC $12646^{\mathrm{T}}$, exhibit good growth over a temperature range of $1-25{ }^{\circ} \mathrm{C}$. The word 'psychrophilic' is here used only to describe a micro-organism that can grow in a cold environment, since the definition of psychrophilic given by Morita (1975), which was based on temperature ranges over which growth occurs and on optimum growth temperatures evaluated via growth rates, has been shown to be ambiguous and inappropriate (Feller \& Gerday, 2003; Margesin, 2009).

Strains Cr4-12 ${ }^{\mathrm{T}}$ and $\mathrm{Cr} 4-35^{\mathrm{T}}$ could be easily differentiated from each other by their growth characteristics (growth of strain $\mathrm{Cr} 4-35^{\mathrm{T}}$ was significantly delayed compared with that of strain $\mathrm{Cr} 4-12^{\mathrm{T}}$ ), colony morphology (strain Cr4-35 ${ }^{\mathrm{T}}$ formed much smaller colonies than strain $\mathrm{Cr} 4-12^{\mathrm{T}}$ ), several physiological properties (Table 1) and polar lipid profiles (see above). Phenotypic characteristics that can be used to distinguish the two novel strains and their four closest phylogenetic neighbours are shown in Table 1. Unfortunately, little is currently known about the polyamines and polar lipids of three of the four species used for reference in this study (i.e. $P$. naphthalenivorans, $P$. hydrogenivorans and $P$. jejuensis). Both strain Cr4- $12^{\mathrm{T}}$ and strain $\mathrm{Cr} 4-35^{\mathrm{T}}$ did, however, contain more putrescine and less 2-hydroxyputrescine than $P$. aquatica CCUG $39402^{\mathrm{T}}$. The polar lipid profile of strain $\mathrm{Cr} 4-12^{\mathrm{T}}$ contained fewer unidentified aminolipids than that of $P$. aquatica CCUG $39402^{\mathrm{T}}$, whereas the polar lipid profile of strain $\mathrm{Cr} 4-35^{\mathrm{T}}$ contained none of the unidentified phospholipids found in P. aquatica CCUG $39402^{\mathrm{T}}$. Based on the phenotypic and phylogenetic evidence and DNA-DNA relatedness data, strains $\mathrm{Cr} 4-12^{\mathrm{T}}$ and $\mathrm{Cr} 4-35^{\mathrm{T}}$ represent two novel species within the genus Polaromonas, for which the names Polaromonas glacialis sp. nov. and Polaromonas cryoconiti sp. nov., respectively, are proposed.

\section{Description of Polaromonas glacialis sp. nov.}

Polaromonas glacialis (gla.ci.a'lis. L. fem. adj. glacialis icy, frozen, full of ice, referring to the frozen, icy environment from which the species was isolated).

Cells are aerobic, Gram-staining-negative, non-motile and coccoid (measuring $0.6-0.8 \times 0.8-1.0 \mu \mathrm{m}$ and often occurring in chains after 7 days at $20{ }^{\circ} \mathrm{C}$ on R2A agar). Colonies on R2A agar are creamy white, slimy, convex and round with entire margins and measure $1.0-1.5 \mathrm{~mm}$ in diameter after 14 days at $20{ }^{\circ} \mathrm{C}$. Grows well at $1-25{ }^{\circ} \mathrm{C}$ but does not grow at $30{ }^{\circ} \mathrm{C}$. Grows at $\mathrm{pH} 6-7$ and with $0-1 \%$ (w/v) NaCl. Grows on R2A agar, NA and TSA. Vitamins are not required for growth. Positive for catalase, cytochrome $c$ oxidase, acid phosphatase, naphthol-AS-BIphosphohydrolase and leucine arylamidase activities and nitrate reduction. Weakly positive for alkaline phosphatase, lipase (C14), valine arylamidase and amylase activities. Negative for indole production from tryptophan, aesculin and gelatin hydrolysis, $\mathrm{H}_{2} \mathrm{~S}$ production, utilization of citrate, and urease, trypsin, $\alpha$-chymotrypsin, protease (skimmed milk), $\alpha$-galactosidase, $\beta$-galactosidase, $\alpha$-glucosidase, $\beta$-glucosidase, $\alpha$-mannosidase, $\alpha$-fucosidase, $N$-acetyl$\beta$-glucosaminidase, tryptophan deaminase, arginine dihydrolase, lysine dihydrolase and ornithine dihydrolase activities. Assimilates Tween 40 and Tween 80 but not D-glucose, sucrose, L-arabinose, D-arabinose, D-mannose, maltose, Dmannitol, $\mathrm{N}$-acetyl-D-glucosamine, malic acid, adipic acid, capric acid, phenylacetic acid, D-sorbitol, myo-inositol, salicin, potassium gluconate or trisodium citrate. Negative for fermentation of D-glucose, D-mannitol, sucrose, inositol, sorbitol, L-rhamnose, melibiose, amygdalin and L-arabinose. The predominant cellular fatty acids are summed feature 3 $\left(\mathrm{C}_{16: 1} \omega 7 c\right.$ and/or $\left.\mathrm{C}_{16: 1} \omega 6 c\right), \mathrm{C}_{16: 0}$ and $\mathrm{C}_{18: 1} \omega 7 c$. The sole ubiquinone is Q-8. The polar lipid profile comprises phosphatidylglycerol, diphosphatidylglycerol, phosphatidylethanolamine, one unidentified aminolipid, three unidentified phospholipids and five unidentified polar lipids. The major polyamines are putrescine and 2-hydroxyputrescine.

The type strain, Cr4-12 ${ }^{\mathrm{T}}\left(=\mathrm{DSM} 24062^{\mathrm{T}}=\mathrm{LMG} 26049^{\mathrm{T}}\right.$ $=$ KACC $15089^{\mathrm{T}}$ ), was isolated from alpine glacier cryoconite collected from the Pasterze/Großglockner glacier in the Hohe Tauern, Austria. The genomic DNA G + C content of the type strain is $61.3 \mathrm{~mol} \%$.

\section{Description of Polaromonas cryoconiti sp. nov.}

Polaromonas cryoconiti (cry.o.co.ni'ti. N.L. gen. n. cryoconiti from cryoconite, the material from which the species was isolated).

Cells are aerobic, Gram-staining-negative, non-motile and small, oval, short rods that measure $0.7-0.9 \times 1.1-1.4 \mu \mathrm{m}$ after 7 days at $20{ }^{\circ} \mathrm{C}$ on R2A agar. Colonies on R2A agar are creamy white, convex and round with entire margins and measure $<1.0 \mathrm{~mm}$ in diameter after 21 days at $20^{\circ} \mathrm{C}$. Grows slowly but well at $1-25{ }^{\circ} \mathrm{C}$ (cell yields are highest at $1-10{ }^{\circ} \mathrm{C}$ ) and does not grow at $30{ }^{\circ} \mathrm{C}$. Grows well at $\mathrm{pH} 7$ but only weakly at $\mathrm{pH} 6$ and does not grow in the presence of $1 \%(\mathrm{w} / \mathrm{v}) \mathrm{NaCl}$. Grows on R2A agar, NA and TSA. Vitamins are not required for growth. Positive for catalase, cytochrome $c$ oxidase, alkaline phosphatase, esterase lipase (C8), lipase (C14) and leucine arylamidase activities and nitrate reduction. Weakly positive for acid phosphatase, valine arylamidase and naphthol-AS-BI-phosphohydrolase 
activities. Negative for indole production from tryptophan, aesculin and gelatin hydrolysis, $\mathrm{H}_{2} \mathrm{~S}$ production, utilization of citrate, and urease, trypsin, $\alpha$-chymotrypsin, protease (skimmed milk), amylase, $\alpha$-galactosidase, $\beta$-galactosidase, $\alpha$-glucosidase, $\beta$-glucosidase, $\beta$-glucuronidase, $\alpha$-mannosidase, $\alpha$-fucosidase, $N$-acetyl- $\beta$-glucosaminidase, tryptophan deaminase, arginine dihydrolase, lysine dihydrolase and ornithine dihydrolase activities. Assimilates Tween 40 and Tween 80 well but the assimilation of potassium gluconate, adipic acid and malic acid is weak. Negative for the assimilation of D-glucose, sucrose, L-arabinose, Darabinose, D-mannose, maltose, D-mannitol, $N$-acetyl-Dglucosamine, capric acid, phenylacetic acid, D-sorbitol, myo-inositol, salicin and trisodium citrate. Negative for the fermentation of D-glucose, D-mannitol, sucrose, inositol, sorbitol, L-rhamnose, melibiose, amygdalin and L-arabinose. The predominant cellular fatty acids are summed feature $3\left(\mathrm{C}_{16: 1} \omega 7 c\right.$ and/or $\left.\mathrm{C}_{16: 1} \omega 6 c\right)$ and $\mathrm{C}_{16: 0}$. The sole ubiquinone is $\mathrm{Q}-8$. The polar lipid profile comprises phosphatidylglycerol, diphosphatidylglycerol, phosphatidylethanolamine, three unidentified aminolipids and one unidentified polar lipid. The major polyamines are putrescine and 2-hydroxyputrescine.

The type strain, Cr4-35 ${ }^{\mathrm{T}}\left(=\mathrm{DSM} 24248^{\mathrm{T}}=\mathrm{LMG} 26050^{\mathrm{T}}\right.$ $=$ KACC $15090^{\mathrm{T}}$ ), was isolated from alpine glacier cryoconite collected from the Pasterze/Großglockner glacier in the Hohe Tauern, Austria. The genomic DNA G $+\mathrm{C}$ content of the type strain is $60.7 \mathrm{~mol} \%$.

\section{Acknowledgements}

The authors are grateful to W. Salvenmoser (Institute of Zoology, University of Innsbruck) for performing the transmission electron microscopy. We thank P. Thurnbichler, J. Mair (University of Innsbruck), B. Sträubler and B. Grün (DSMZ) for technical assistance and Dr Hang-Yeon Weon (KACC) for providing us with the type strains of $P$. hydrogenivorans and P. jejuensis. R.M. is grateful for financial support from an 'Aktion D. Swarovski \& Co. 2009' grant from the University of Innsbruck.

\section{References}

Busse, H.-J. \& Auling, G. (1988). Polyamine pattern as a chemotaxonomic marker within the Proteobacteria. Syst Appl Microbiol 11, 1-8.

Busse, H.-J., Bunka, S., Hensel, A. \& Lubitz, W. (1997). Discrimination of members of the family Pasteurellaceae based on polyamine patterns. Int J Syst Bacteriol 47, 698-708.

Cashion, P., Holder-Franklin, M. A., McCully, J. \& Franklin, M. (1977). A rapid method for the base ratio determination of bacterial DNA. Anal Biochem 81, 461-466.

Collins, M. D. (1985). Isoprenoid quinone analysis in classification and identification. In Chemical Methods in Bacterial Systematics, pp. 267-287. Edited by M. Goodfellow \& D. E. Minnikin. London: Academic Press.

Darcy, J. L., Lynch, R. C., King, A. J., Robeson, M. S. \& Schmidt, S. K. (2011). Global distribution of Polaromonas phylotypes - evidence for a highly successful dispersal capacity. PLoS ONE 6, e23742.
De Ley, J., Cattoir, H. \& Reynaerts, A. (1970). The quantitative measurement of DNA hybridization from renaturation rates. Eur $J$ Biochem 12, 133-142.

Feller, G. \& Gerday, C. (2003). Psychrophilic enzymes: hot topics in cold adaptation. Nat Rev Microbiol 1, 200-208.

Felsenstein, J. (1981). Evolutionary trees from DNA sequences: a maximum likelihood approach. J Mol Evol 17, 368-376.

Foght, J. \& Aislabie, J. (2005). Enumeration of soil microorganisms. In Manual of Soil Analysis, pp. 261-280. Edited by R. Margesin \& F. Schinner. Berlin, Heidelberg: Springer-Verlag.

Huß, V. A. R., Festl, H. \& Schleifer, K. H. (1983). Studies on the spectrophotometric determination of DNA hybridization from renaturation rates. Syst Appl Microbiol 4, 184-192.

Irgens, R. L., Gosink, J. J. \& Staley, J. T. (1996). Polaromonas vacuolata gen. nov., sp. nov., a psychrophilic, marine, gas vacuolate bacterium from Antarctica. Int J Syst Bacteriol 46, 822-826.

Jeon, C. O., Park, W., Ghiorse, W. C. \& Madsen, E. L. (2004). Polaromonas naphthalenivorans sp. nov., a naphthalene-degrading bacterium from naphthalene-contaminated sediment. Int J Syst Evol Microbiol 54, 93-97.

Kämpfer, P., Busse, H.-J. \& Falsen, E. (2006). Polaromonas aquatica sp. nov., isolated from tap water. Int J Syst Evol Microbiol 56, 605-608.

Margesin, R. (2009). Effect of temperature on growth parameters of psychrophilic bacteria and yeasts. Extremophiles 13, 257-262.

Margesin, R. \& Schinner, F. (1997). Bioremediation of diesel-oil contaminated alpine soils at low temperatures. Appl Microbiol Biotechnol 47, 462-468.

Margesin, R., Gander, S., Zacke, G., Gounot, A. M. \& Schinner, F. (2003). Hydrocarbon degradation and enzyme activities of coldadapted bacteria and yeasts. Extremophiles 7, 451-458.

Mattes, T. E., Alexander, A. K., Richardson, P. M., Munk, A. C., Han, C. S., Stothard, P. \& Coleman, N. V. (2008). The genome of Polaromonas sp. strain JS666: insights into the evolution of a hydrocarbon- and xenobiotic-degrading bacterium, and features of relevance to biotechnology. Appl Environ Microbiol 74, 6405-6416.

Mesbah, M., Premachandran, U. \& Whitman, W. B. (1989). Precise measurement of the $\mathrm{G}+\mathrm{C}$ content of deoxyribonucleic acid by highperformance liquid chromatography. Int J Syst Bacteriol 39, 159-167.

Morita, R. Y. (1975). Psychrophilic bacteria. Bacteriol Rev 39, 144-167.

Reasoner, D. J. \& Geldreich, E. E. (1985). A new medium for the enumeration and subculture of bacteria from potable water. Appl Environ Microbiol 49, 1-7.

Saitou, N. \& Nei, M. (1987). The neighbor-joining method: a new method for reconstructing phylogenetic trees. Mol Biol Evol 4, 406425.

Sambrook, J., Frisch, E. F. \& Maniatis, T. (1989). Molecular Cloning: $a$ Laboratory Manual, 2nd edn. Cold Spring Harbor, NY: Cold Spring Harbor Laboratory.

Sasser, M. (1990). Identification of bacteria by gas chromatography of cellular fatty acids, MIDI Technical Note 101. Newark, DE: MIDI Inc.

Schlegel, H. G. (1992). Allgemeine Mikrobiologie. Stuttgart: Georg Thieme.

Sizova, M. \& Panikov, N. (2007). Polaromonas hydrogenivorans sp. nov., a psychrotolerant hydrogen-oxidizing bacterium from Alaskan soil. Int J Syst Evol Microbiol 57, 616-619.

Stolz, A., Busse, H.-J. \& Kämpfer, P. (2007). Pseudomonas knackmussii sp. nov. Int J Syst Evol Microbiol 57, 572-576.

Tamura, K., Peterson, D., Peterson, N., Stecher, G., Nei, M. \& Kumar, S. (2011). MEGA5: molecular evolutionary genetics analysis using 
maximum likelihood, evolutionary distance, and maximum parsimony methods. Mol Biol Evol 28, 2731-2739.

Thompson, J. D., Gibson, T. J., Plewniak, F., Jeanmougin, F. \& Higgins, D. G. (1997). The CLUSTAL_X windows interface: flexible strategies for multiple sequence alignment aided by quality analysis tools. Nucleic Acids Res 25, 4876-4882.

Tindall, B. J. (1990a). Lipid composition of Halobacterium lacusprofundi. FEMS Microbiol Lett 66, 199-202.

Tindall, B. J. (1990b). A comparative study of the lipid composition of Halobacterium saccharovorum from various sources. Syst Appl Microbiol 13, 128-130.

Wayne, L. G., Brenner, D. J., Colwell, R. R., Grimont, P. A. D., Kandler, O., Krichevsky, M. I., Moore, L. H., Moore, W. E. C., Murray, R. G. E. \& other authors (1987). International Committee on Systematic Bacteriology. Report of the ad hoc committee on reconciliation of approaches to bacterial systematics. Int J Syst Bacteriol 37, 463-464.

Weon, H. Y., Yoo, S. H., Hong, S. B., Kwon, S. W., Stackebrandt, E., Go, S. J. \& Koo, B. S. (2008). Polaromonas jejuensis sp. nov., isolated from soil in Korea. Int J Syst Evol Microbiol 58, 1525-1528.
Wu, C., Lu, X., Qin, M., Wang, Y. \& Ruan, J. (1989). Analysis of menaquinone compound in microbial cells by HPLC. Microbiology (English translation of Microbiologiia) 16, 176-178.

Yagi, J. M., Sims, D., Brettin, T., Bruce, D. \& Madsen, E. L. (2009). The genome of Polaromonas naphthalenivorans strain CJ2, isolated from coal tar-contaminated sediment, reveals physiological and metabolic versatility and evolution through extensive horizontal gene transfer. Environ Microbiol 11, 2253-2270.

Zhang, D.-C., Schinner, F. \& Margesin, R. (2010). Pedobacter bauzanensis sp. nov., isolated from soil. Int J Syst Evol Microbiol 60 , 2592-2595.

Zhang, D.-C., Busse, H.-J., Liu, H.-C., Zhou, Y.-G., Schinner, F. \& Margesin, R. (2011). Sphingomonas glacialis sp. nov., a psychrophilic bacterium isolated from alpine glacier cryoconite. Int J Syst Evol Microbiol 61, 587-591.

Zhang, D.-C., Redzic, M., Liu, H.-C., Zhou, Y.-G., Schinner, F. \& Margesin, R. (2012). Devosia psychrophila sp. nov. and Devosia glacialis sp. nov., from alpine glacier cryoconite, and an emended description of the genus Devosia. Int J Syst Evol Microbiol 62, 710-715. 